University of Nebraska - Lincoln

DigitalCommons@University of Nebraska - Lincoln

$1-1957$

\title{
The Relation of Spring Bird Distribution to a Vegetation Mosaic in Southeastern Washington
}

\author{
Paul A. Johnsgard \\ University of Nebraska-Lincoln, pajohnsgard@gmail.com \\ W. H. Rickard \\ Washington State University
}

Follow this and additional works at: https://digitalcommons.unl.edu/johnsgard

Part of the Ornithology Commons

Johnsgard, Paul A. and Rickard, W. H., "The Relation of Spring Bird Distribution to a Vegetation Mosaic in Southeastern Washington" (1957). Paul Johnsgard Collection. 3.

https://digitalcommons.unl.edu/johnsgard/3

This Article is brought to you for free and open access by the Papers in the Biological Sciences at DigitalCommons@University of Nebraska - Lincoln. It has been accepted for inclusion in Paul Johnsgard Collection by an authorized administrator of DigitalCommons@University of Nebraska - Lincoln. 


\section{INTRODUCTION}

Climax vegetation is of particular interest for study since it is the oldest and most stable vegetation of a region and should be expected to have a distinctive complement of animals. The purpose of this investigation was to observe the predilection of birds for stands representing climax plant associations in a remnant of native grassland in southeastern Washington.

The grasslands of this region were rapidly converted from grazing use to wheat production beginning about 65 years ago (Daubenmire 1942) and as a result only a few scattered remnants of native vegetation remain today. Associated with changes in vegetation there have been changes in the animal complement of the region (Buechner 1953; Buss and Dziedzic 1955).

Opportunities to observe birds in native grassland are scarce. Published records on breeding birds in native Festuca idahoensis grassland are those of: (1) Wing (1949), (2) Booth (1952) who described the ecological distribution of birds in the grassland areas of the Blue Mountains region of Washington and Oregon but failed to differentiate between the Agropyron and Festuca grassland zones, and (3) Dumas (1950) who also determined the distribution of breeding birds in southeastern Washington and largely followed the classification of vegetation proposed by Daubenmire (1942).
Location and Vegetation of the Study Area

The study area is a 28 -acre tract of native Festuca idahoensis grassland vegetation located 13 miles southwest of Pullman, Washington, and is situated near the southern edge of the Festuca grassland zone (Daubenmire 1942). The area has been preserved from plowing by fortuitous circumstances and consists primarily of an eastwest ridge estimated to be about 75 feet higher than the surrounding landscape.

The area lies at the ecotone between the Festuca grassland and the Agropyron grassland which borders the north barik of the Snake River. The south-facing slopes and exposed ridges are occupied by stands representing the Agropyron / Poa association while the north-facing slopes and protected sites are occupied by stands of two more-mesophytic associations, Symphoricarpos / Festuca and Festuca / Symphoricarpos. These latter associations are distinguished by physiognomy for they both have essentially the same species composition.

Stands of the Symphoricarpos / Festuca association are dominated by deciduous shrubs, Symphoricarpos rivularis, Rosa spaldingii, Rosa ultramontana and Prunus virgiana var. melanocarpa with occasional inclusions of Crataegus douglasii and Amelanchier alnifolia. These shrubs form dense thickets usually 0.5 to 1 meter in height. The herbaceous plants subordinate to the shrub canopy are for 
the most part the same as those in the adjacent grassland.

The Festuca / Symphoricarpos association, forming the matrix around the thickets, is dominated by the tall perennial grasses, Festuca idahoensis and Agropyron spicatum, with a rich assortment of forbs such as Hieracium albertinum, Helianthella douglasii, Senecio integerrimus var. exalta, Potentilla flabelliformis, Geum ciliatum and others. The shrubs present are the same as those in the thickets; however, they are scattered, strongly dwarfed and short lived. They seldom attain the height of the mature grasses, hence the physiognomy appears as a more or less even herbaceous sward.

The Agropyron / Poa association occupying the southfacing slopes presents a characteristic "bunchy" physiognomy as a result of the wide spacing and caespitose habit of Agropyron spicatum, the dominant plant of this habitat. Balsamorhiza sagittata, a large perennial forb, may be locally abundant. The Poa union consists of Poa secunda and dwarf annual dicots such as Draba verna and Collinsia parififora which occur betwen the Agropyron bunches. These plants are small and they dry earlier in the season than do other vascular plants.

\section{METHODS}

Twelve trips were made to the study area from March 26 to June 22, 1955, inclusive; the first two trips were separated by a two-week interval, the remaining ten were at weekly intervals. A map showing the distribution of the plant associations occuring on the area was prepared. All birds observed on the area, with the exception of those seen only in flight, were located on this map, thus aiding in relating field observations to territorial boundaries. In addition, records were taken for total birds observed, by associations, during each visit.

\section{Observations}

Total bird-use in each of the three associations is indicated in Table I. In this table, "Total" equals the total individuals of each species recorded for a given association, and "Frequency" equals the percentage of trips for which a particular species was recorded in a given association. Only species with frequencies greater than $10 \%$ are included in his table. The species are arranged according to habitat preferences from xeric to mesic, i.e. Agropyron / Poa, Festuca / Symphoricarpos, Symphoricarpos / Festuca (McMinn 1952; Murdock and Rickard 1956).

Wing (1949) determined the size of the study area as approximately 28 acres. Of this 50 percent is estimated to be occupied by stands of the Festuca / Symphoricarpos association. Each of the other two associations is estimated to cover approximately 25 percent. As a means of providing an adequate comparison between associations, bird abundance has been calculated on the basis of total birds per estimated 10 acres. This calculation indicates that the Symphoricarpos / Festuca association is approximately 20 times as useful to birds as is either of the other two associations. Since some duplication probably occurred this estimate must not be considered to be a census figure. However, as duplication can be assumed to be nearly proportional among the associations, the comparison of relative abundance seems a valid one.

TABLE I. Bird distribution, March 26-June 22, 1956. Species having maximum frequencies of less than ten per cent omitted

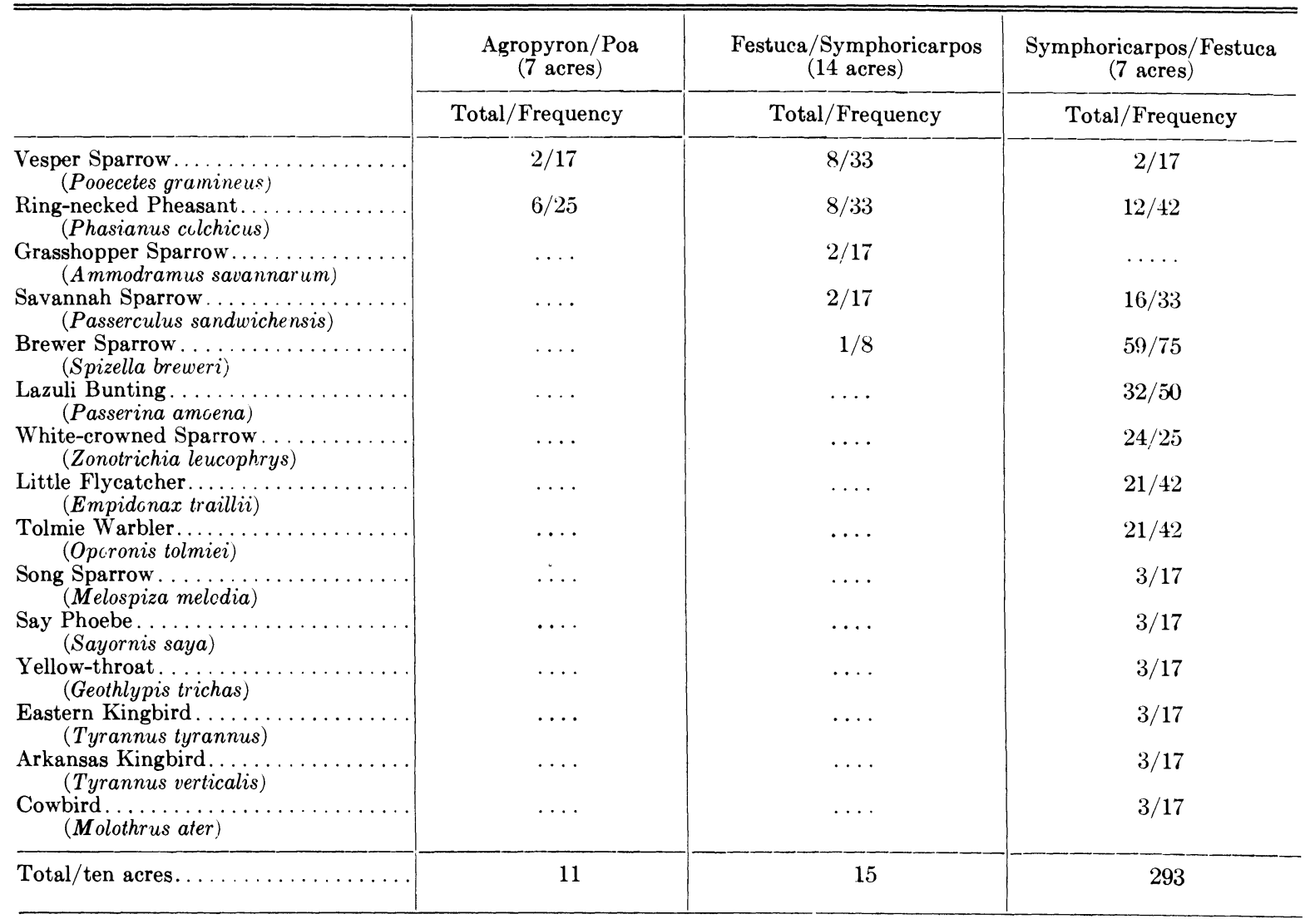


The above comparison refers to all bird species observed in the study area, including migrants. If only species known to breed in the region are taken into consideration, an additional comparison can be made. To estimate total breeding pairs it was necessary to draw in probable territories for each breeding species. A minimum requirement of at least three observations of a species (usually a singing male) in a restricted area was selected for designating a probable territory. These figures were then converted into "Estimated territories per 10 acres" (Table II). Degree of "Fidelity" to a particular association was determined by calculating the total individuals of each species recorded for a given association as a percentage of the total individuals of that species recorded for all three associations.

TABLE II. Estimated territories per ten acres, March 26June 22,1956 , based on a minimum of three observations per estimated territory

\begin{tabular}{l|c|c|c}
\hline \hline & $\begin{array}{c}\text { Agro- } \\
\text { pyron/Poa }\end{array}$ & $\begin{array}{c}\text { Festuca/Symphori- } \\
\text { carpos }\end{array}$ & $\begin{array}{c}\text { Symphoricarpos/ } \\
\text { Festuca }\end{array}$ \\
\cline { 2 - 3 } & Pairs/Fidelity & Pairs/Fidelity & Pairs/Fidelity \\
\hline Ring-necked Pheasant & $1 / 23$ & $1 / 31$ & $1 / 46$ \\
Vesper Sparrow...... & $0 / 12$ & $1 / 75$ & $0 / 12$ \\
Savannah Sparrow.... & $\ldots$ & $1 / 11$ & $0 / 89$ \\
Brewer Sparrow...... & $\ldots$ & $0 / 2$ & $17 / 98$ \\
Lazuli Bunting...... & $\ldots$ & $\ldots$ & $9 / 100$ \\
Tolmie Warbler...... & $\ldots$ & $\ldots$ & $7 / 100$ \\
Little Flycatcher..... & $\ldots$. & $\ldots$. & $7 / 100$ \\
Total territories/ & $\ldots$ & 3 & 31 \\
ten acres........ & 1 & & \\
\hline
\end{tabular}

A comparison of the total estimated breeding pairs per 10 acres reveals a significant variation in the relative value of the different associations. The Symphoricarpos / Festuca association is apparently over 30 times more valuable to breeding birds than the Agropyron / Poa association and about 10 times more valuable than the Festuca / Symphoricarpos association. It should not be overlooked, however, that species such as the Savannah sparrow may nest on the ground in the Festuca / Symphoricarpos association but utilize the Symphoricarpos / Festuca association for territorial perches.

A comparison of the bird populations observed during this study with those observed by Wing (1949) shows that there has been almost no change in the total numbers of breeding birds utilizing the study area. During the years 1942-1947 Wing found little variation in total numbers of breeding bird pairs from year to year (i.e. from 32 to 36.5 pairs), although there were minor variations in species composition. Nevertheless, in each of the years studied, the Brewer sparrow and lazuli bunting were first and second in abundance respectively. As indicated in Table III, the four most abundant species observed in 1956 were in almost identical sequence and density as Wing's five-year averages. The conclusion is that a distinctive and stable bird population is associated with this tract of climax vegetation.

A direct comparison of bird utilization with all three plant associations with Wing's findings is not possible. Although Wing indicated that the most common breeding birds were associated with the brush patches (i.e. stands of the Symphoricarpos / Festuca association) he recognized only two vegetation types for the study area; (1) Agropyron / Festuca which included stands of both the Festuca / Symphoricarpos and Symphoricarpos / Festuca associations and (2) Agropyron / Poa.
TABLE III. Total estimated breeding pairs

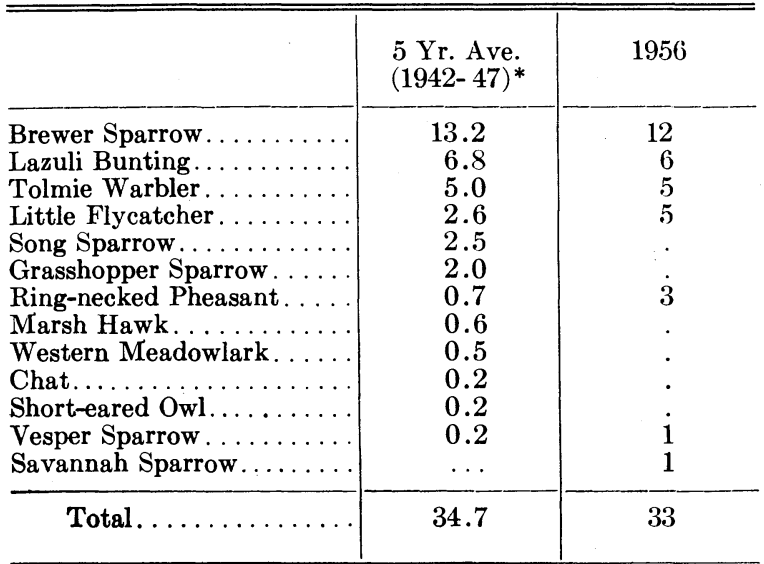

*Data from Wing (1949).

The small amount of bird usage of the Agropyron / $P o a$ association (Table I) corroborates the findings of Wing who observed that only one native bird, the vesper sparrow, nested in stands of this association.

\section{Discussion}

The difference in bird usage observed between the three plant associations studied is striking. The discrepancy between the value of the Symphoricarpos / Festuca and the Festuca / Symphoricarpos associations is of particular importance, since the major difference between these two associations is their physiognomy.

Reasons for the value of a shrub-dominated plant community become apparent when one considers the importance of protective cover, territorial perches, and nest sites for species such as the Brewer sparrow, lazuli bunting, and Tolmie warbler. The Brewer sparrow well illustrates the principle of importance of community physiognomy rather than dependence on a particular plant species. In the Artemisia / Agropyron association of more arid regions the Brewer sparrow is common (Dumas 1950; Booth 1952); here Artemisia tridentata provides the necessary shrub component. In the semistabilized dune area of the Moses Lake "Potholes" region and in the Agropyron / Poa zone, the presence of Chrysothamnus satisfies the perch requirements of the Brewersparrow (Johnsgard 1955). In the present study area Crataegus, Prunus, and Amelanchier, which tend to rise above the level of the other shrubs, are the usual perches and nest sites for the species. The Brewer sparrow is thus found in different plant associations, but always those with shrubs to serve as perches. Dumas (1950) found the lazuli bunting and Tolmie warbler to be abundant in nine bark (Physocarpus) thickets, which are similar in their physiognomy to the Symphoricarpos thickets, but which have a different floristic composition and occur in a more moist region.

Fence lines in the Festuca grassland zone, by contributing to the preservation of shrub communities in territory planted to wheat or peas, have great value as cover for game birds and nesting sites for certain song birds that would otherwise be extirpated from the upland portions of the Festuca grassland zone.

\section{Acknowledgments}

The writers are grateful to Dr. I. O. Buss and to Dr. R. Daubenmire for the helpful suggestions made during the preparation of this paper. 
Summary and Conclusions

A 28-acre relict stand of native vegetation located near Pullman, Washington, was studied between March 26 and June 22, 1956 to determine bird distribution patterns. Birds were classified as to their occurrence in the three climax plant associations: Agropyron / Poa, Festuca / Symphoricarpos, and Symphoricarpos / Festuca. It wa: found that the Symphoricarpos / Festuca association provided a habitat that showed approximately 20 times greater utilization than either of the other two associations. On the basis of estimated breeding pairs, the Symphoricarpos / Festuca association showed approximately 30 times more utilization than the Agropyron / $P o a$ association and about 10 times more utilization than the Festuca / Symphoricarpos association. Breeding bird density and species composition were similar to those of populations observed on the same study area by Wing (1949) during the years 1942-1947, indicating a stability of bird populations in this climax mosaic. It was further concluded that the shrubby physiognomy of the Symphoricarpos / Festuca association, rather than its particular floristic composition, accounted for its more frequent utilization.

\section{ReFERENCES}

Booth, E. S. 1952. Ecological distribution of the birds of the Blue Mountains region of southeastern Washington and northeastern Oregon. Walla Walla College, Pub. Dept. Biol. Sci. and Biol. Sta., No. 7 : 65107.

Buechner, H. K. 1953. Some biotic changes in the state of Washington, particularly during the century
1853-1953. Res. Studies, State College of Waashington, 21: 154-192.

Buss, I. O. and E. S. Dziedzic. 1955. Relation of cultivation to the disappearance of the Columbian sharptailed grouse from southeastern Washington. Condor, 57: 185-187.

$\rightarrow$ Daubenmire, R. F. 1942. An ecological study of the vegetation of southeastern Washington and adjacent Idaho. Ecol. Monogr., 12: 53-79.

Dumas, P. G. 1950. Habitat distribution of breeding birds in southeastern Washington. Condor, 52: 232237.

Johnsgard, P. A. 1955. The relation of water level and vegetational changes to avian populations, particularly waterfowl. M.S. thesis, State College of Washington, Pullman. 167 pp.

McMinn, R. G. 1952. The role of soil drought in the distribution of vegetation in the northern Rocky Mountains. Ecology, 33: 1-15.

Murdock, J. R., and W. H. Rickard. 1956. The relationships of soil moisture and temperature among certain grassland associations of southeastern Washington. Northwest Sci., 30: 99-103.

Wing, L. 1949. Breeding birds of virgin Palouse prairie. Auk, 66: 37-40.

\section{P. A. JOHNSGARD}

W. H. RICKARD

Department of Zoology and

Department of Botany,

The State College of Washington, Pullman, Washington 